Physics and the Solar Physics Observatory. This determined my whole career, for in $1893 \mathrm{I}$ became Sir Norman's assistant on the staff of Nature and succeeded him as Editor in 1919. With these early recollections in mind, and knowing the high scientific standing of the members of the staff of the Imperial College since my days, it would be almost a presumption for me to add my testimony to its greatness. I shall, however, always cherish in my heart the influence the College has had on my life, and entertain with pride the feeling that $I$ once played a minor part in the work of a branch of this great centre of scientific learning and research.

DR. W. H. Eccles, F.R.S., formerly professor of applied physics and electrical engineering, City and Guilds of London Technical College :

In the closing years of the nineteenth century, when I was admitted to the Royal College of Science, I found it a well-established and bustling community. Nearly all my fellow-students seemed to be remarkably mature and responsible beings who had already had experience in science-teaching, in works or in laboratories. They, rather than the staff, created the atmosphere of the College, which might be described as one of altruistic utilitarianism ; many of them were reading science in order to assist industrial progress, each in his original walk of life. Moreover, the wise men who had made the College syllabuses had fostered this atmosphere in advance by ensuring that the instruction should be on a Baconian not a Platonic basis.

Active discussion with one's fellow-students showed that this strong orientation toward usefulness intensified the desire to read 'pure' science, a desire which merely gave expression to the spreading opinion that the important changes in industry would henceforth come from accurate measurement and the scientific method rather than from the method of the craftsman, and that new processes and even new industries could spring only from new scientific discoveries. Men like Armstrong, Judd, Huxley and Magnus had been preaching this doctrine for some twenty years, and had aided in setting up at South Kensington not only the Royal College of Science, but also the School of Mines and the Central Technical College of the City and Guilds of London Institute, all of which are now components of the Imperial College.

The gratitude I feel for my five years of opportunity at the Royal College of Science (plus occasional lectures at the Central) is deepened by the assessment I obtained there of the functions of science in the modern world. A new and broader meaning was given to the word 'technology' which, according to the dictionary, is the 'science of the industrial arts', but which now appeared to be 'science for the industrial arts, existing and to come'. If only there had been at the Royal College of Science research courses in the application of modern science to problems in nascent industries, I should have departed even more indebted to the College; as it was, I became one of Marconi's assistants and was launched on the practical world in that way.

Looking back at the careers of my contemporaries at the College, I find that nearly all of them took up the task of introducing science, in one way or another, into industrial affairs; I know of many who have done much for industry. May the modern Imperial College be increasingly successful in moulding such pioneers.
Sir WrLliam Jarratt, formerly ComptrollerGeneral of Patents, Designs and Trade Marks :

It is an appreciated privilege to be allowed to join the chorus of congratulations on the Imperial College centenary celebrations. During the years 1887-90, when I was a student at the College, the changes that were occurring included the amendment of the name and status of the Normal School of Science to the Royal College of Science, and I well remember my delight that my leaving certificate was signed by that great controversialist Huxley, the dean of the School and College, and by the founder and first editor of Nature, Sir Norman Lockyer, better known to readers of Punch as 'Noman Luckier'.

In those years research posts, either in industry or at universities, were not plentiful, and in consequence many students became science masters or took posts in the Civil Service such as Patent Office examinerships. With Govərnment encouragement, however, the importance of research became increasingly recognized, and more students availed themselves of the opportunities to follow up scientific research. It is a matter for congratulation that during this development the College authorities have never ceased to recognize that side by side with scientific research, long-term or otherwise, the industrial development and the social conditions of Britain necessitate the application of the results of research, and that this industrial application is stimulated by a strong patent law such as we fortunately possess. The best results from scientific research can scarcely accrue to the State without some such form of guarantee to those enterprising industrialists who take financial risks in applying to industry the results of research.

As the years have passed it has been a pleasure to watch the steady development of the College and its increasing influence among the forces that have retained for Great Britain its position in the forefront of scientifie progress. I desire to congratulate heartily the College authorities on their magnificent record.

\section{CONTRIBUTIONS OF THE IMPERIAL COLLEGE TO THE CONQUEST OF DISEASE*}

\author{
By the RIGHT HON. LORD RAYLEIGH, F.R.S.
}

$\mathrm{O}$

$\mathrm{N}$ an occasion like this it is natural to take stock of the work we and our predecessors have been able to accomplish since the first beginnings of the College a hundred years ago. But this work covers so wide a range, and so many different specialities in all branches, from physics and engineering on one side to zoology on the other, that in the course of a short address one cannot even glance at all aspects of it. Looking for some fairly comprehensive topic to which a good many of our departments had contributed, I was struck by the victories which had been won over the ageneies of disease. It might appear at first sight that this was a matter of medical science, with the obvious comment that none of our departments deals with that subject. Important though the medical applications are, these investigations have been developed rather from the point of view of physics and chemistry. But there is no need to emphasize professional aspects of this kind.

* Introductory address for the Centenary Celebrations on October 25. 
These problems are so vital to all of us that we must use any and every method to solve them, and accept help from any quarter. The civil engineer would at one time have said that entomology had nothing to do with him. Nevertheless, he was defeated in the attempt to make the Panama Canal until he had accepted the help of the entomologist in dealing with yellow fever, and the mosquitoes that transmit it.

Our efforts have recently been concentrated on overcoming our human enemies. Formidable though these have been, there is another class of enemies whose methods are very different, but whose fundamental purpose is for the most part the same, namely, to promote their own well-being at the expense of ours. They are to be found among certain of the lower forms of life, the microbes, which are primarily responsible for fevers and infection, and the insect bearers of disease, which play an equally important if not quite so insidious a part in conveying the microbes to the scene of action. It is only in modern times that these enemies have been recognized as such : and even now many people talk glibly about microbes with little or no understanding of how we have learnt that they are of the essence of disease, that they are in the food we eat, the water that we drink, and the air we breathe. Not only are the lower forms of life constantly lying in wait to attack life and health, but they are also formidable competitors for our food supply, and can rarely be altogether prevented from taking their toll of it.

The late Sir Alfred Keogh, director and reorganizer of the Army Medical Service, and afterwards rector of the Imperial College, told me an incident which may serve to illustrate this. The scene was the Army Council, of which he was, of course, the only medical member. He urged the introduction of certain hygienic measures, explaining briefly the reasons for them. Not much was said by his more purely military colleagues, but one of them, a general who had distinguished himself greatly in the South African War, came up to him afterwards and said: "I was very glad to support you in what you wanted done; but, tell me as man to man, do you really believe in microbes ?" Keogh, rather at a loss for words, could only insist on his coming to see them for himself.

I will now try to sketch in outline how this belief gradually forced itself on the scientific world, illustrating the story as far as possible by the investigations made in the Imperial College.

It had become widely recognized that the spread and multiplication of fever cases had many points of resemblance to the spread and multiplication of living beings. Thus each species of plants or animals multiplied according to its own kind; and fever cases did the same. Smallpox gave rise to smallpox and to nothing else; typhoid fever gave rise to typhoid fever and to nothing else. The infection starting from a single case could give rise to an unlimited number of others, and putrefaction was one single phenomenon, whether it occurred in the wounds of the living, or in dead bodies of men or animals.

On the other hand, observation seemed to show that exposure to the air was the essential condition for putrefaction. For meat broth, boiled to expel air and sealed up in glass flasks, would remain clear and free from putrefaction for an indefinite period. If the sealed flask was opened to admit air, putrefaction quickly set in. The same thing is now familiar to everyone in cans of tinned meat. This remains good indefinitely until it is opened and the air is admitted. These contrasting facts appeared to Tyndall's generation very contradictory. There appeared to be no doubt that putrefying animal matter was swarming with life, for it could be observed under the microscope that this was the case; and since there was no obvious source for this life to have come from, many were of opinion that it must have been generated in the putrefying matter. This question was, in fact, whether there was spontaneous generation of life or not. No question could be of greater importance. It was urged by some that since life existed on the earth, it must have come into existence since the earth was formed; and if this had happened once, it was reasonable and in accordance with the scientific habit of mind to assume that it would happen again in similar circumstances: and they thought it obviously did happen under observation when meat became putrid. Tyndall, however, was not satisfied by this reasoning; and I will try to give an account of his contribution to the subject.

In his researches on radiant heat, and in his experimental lectures at the Royal Institution and at this College, he had been in the habit of making use of the electric arc to throw out a concentrated beam of light, and he observed how the track of the beam could be traced by the way in which it illuminated the dust particles in the air. Most of us are now pretty familiar with this, because of the searchlights used in war. It was not so commonplace then, and I may recall that the only source of current for the electric arc, or at any rate, the source in general use, was a primary battery of forty or fifty Grove cells, very tedious and troublesome to set up and maintain. Tyndall tried whether he could not get rid of the dust in air. He found this difficult at first, but ultimately succeeded by filtering the air through tightly packed cotton-wool. When he did this, he found that the track of the beam became invisible, and the air through which it passed was, as he expressed it, optically empty.

$\mathrm{He}$ prepared specimens of broth from various kinds of meat and fish, and boiled them in order to kill any living matter they might contain. Then he found that such broths would putrefy when they were exposed to ordinary air, but not when they were exposed to air which had been freed from dust, and which showed no motes in a concentrated beam of light. Ordinary air caused putrefaction. Dust-free air did not. These simple tests went far to resolve a great and fundamental question. The putrid broth which had been exposed to the open air was soon found to be swarming with living matter, visible as such under the microscope. Where did it come from in the first instance ? Was it generated in the liquid? That was the opinion of one prominent school of thought; but Tyndall's experiment showed that if all living matter was killed by boiling, exposure to the air would not generate any more. Life only comes from life, and however much appearances may at first sight suggest the contrary, it is not generated anew under our eyes.

Tyndall's researches ran to a great extent parallel with the famous investigations of Pasteur, with whom he was in touch. Without prejudice to workers elsewhere, we on the present occasion naturally dwell on the contribution of our professor, made by a method entirely his own, which led him to important discoveries in other directions also; for example, the artificial imitation of the blue sky, and its optical peculiarities_-far enough, one might think, from problems of infection, disease and the origin of life.

Bacteria are not only very small, but also they are 
colourless, and it is only after they have been stained that it becomes reasonably easy to investigate or even see them. It is found that one class of bacteria will take up one class of stain, exemplified by methyl violet, and other bacteria will take up a different class of stain, exemplified by fuchsin, which is red. The reason for this is somewhat obscure, but whatever the reason, the fact is very helpful in distinguishing between the various bacteria. I have entered on this subject because I wished to recall that the aniline dyes used for this purpose, and also for such minor purposes as colouring our clothes, carpets, curtains, cushions, had their origin in this College in 1856, when W. H. Perkin discovered mauve. He was not a professor, but a student under Hofmann, and was only eighteen years old. He immediately took the matter up commercially, though Hofmann did not encourage this, and Perkin himself had never even been inside a chemical factory before. It sounds like a fairy tale, but he made a fortune out of it, and retired to pursue his studies in pure science.

I have mentioned methyl violet and fuchsin. These were among the discoveries of A. W. Hofmann, who succeeded Playfair as professor and by whom Perkin was trained. It may be a little confusing to be told that the first aniline dye was discovered by the youthful pupil and the later ones by the professor, but so it was.

The famous name of Hofmann, who was brought here by the personal influence of the Prince Consort, leads to another aspect of our main topic. Much anxiety had been caused in the early sixties of the last century by the questions of the purity of water supply and of the disposal of sewage. Pure water in great cities is now almost taken for granted. This has not always been so. When Catherine of Aragon came to England as a bride, she was warned not to drink water in England as it was not fit to drink, and as regards the low-lying land of the southern counties this was doubtless quite true. Coming to a much later period, I can remember, probably about 1885, when I made as if to help myself to a glass of water in the waiting room at Liverpool Street Station, that I was warned never to drink water in such places! The warning may have been somewhat out of date, but not by much, for surface wells were still in use in some parts of central London as late as 1867, when the water from them was found on analysis to be disgustingly polluted, and quite unfit for human consumption.

Hofmann first gave attention to the subject of water analysis at the same time that he was at work on the aniline dyes, but he had scarcely got his teeth into the problem before he left Britain for good and was succeeded in his professorship at the College by Sir Edward Frankland, who took up the question with great vigour, and examined anew for himself the various methods of analysis which had been in use, with the result that he found that on some of them, at least, little reliance could be placed.

I ought to explain more clearly what is meant by water analysis in this connexion. We are not, of course, speaking of mineral or medicinal water but merely of drinking water; and the vital question is, Has it been contaminated by contact with foul matter ? Very little definite was known about microorganisms at that time. But Frankland already considered it more than probable from the history of past outbreaks of typhoid fever in various places that the infection could be carried by drinking water, and that a specific poison associated with this disease must exist. For bad though the position was, it was only exceptional specimens of foul water that gave typhoid fever, so that foulness was not enough by itself. No one, however, knew at that time what this agent was, or how to test for its presence; and indeed, we have no very practicable direct test of this kind even now, though we understand a great deal more about what the source of mischief is and how to guard against it.

In the absence of a direct and easy test as to whether the water is actually infected, we have to fall back on indirect tests as to whether it has been exposed to contamination, and these are found in seeing how far the water contains ammonia and nitrates. These substances are harmless enough in themselves, but they contain nitrogen, and as Frankland proved in detail, it is usually pretty certain that they got their nitrogen from highly undesirable sources. So an analysis for these tells us a great deal as to whether the water can be trusted.

Having established these and other methods, he put them extensively into practice, and examined the water in London and in various parts of England. The result was broadly to confirm that there was a very great difference between surface water from the Thames and Lee Vålley for example, and that from deep wells sunk in the chalk or the greensand. The test of analysis on the lines explained showed that the shallow-well water in the Thames Valley, though it might look and taste quite good, was really little better than filtered sewage.

The idea prevails rather widely that we can readily decide whether a sample of drinking water is safe by looking for the presence of typhoid bacilli. Unfortunately, to look for the typhoid bacillus in drinking water is like looking for a needle in a haystack. It might succeed in the case of extreme contamination, but it is not easy enough or certain enough to be a practical procedure. Bacteriological examination is of the greatest value, but like the chemical methods it only leads to general conclusions, and by no means supersedes those methods.

The development of our knowledge of bacteria is by far the greatest contribution ever made to the study and prevention of disease ; for it has given us not only the modern mastery of infectious diseases, but also has made possible the great advances in surgery. I have tried to bring home to you that our College has had its fair share in their development. But we must now turn to another subject, kindred to this one, and of comparable importance. That is the control of insect pests.

Man flatters himself that he is the 'Lord of Creation'; but the insects do not show themselves impressed with this point of view, and usually go on their own way, hostile to man, and treating his pretensions with very little respect. It has always been known that some species, such as the scorpion and the tarantula spider, might on occasion be dangerous; but it is only in comparatively recent times that we have understood how many and how formidable are our enemies in the insect world.

The man of science feels intuitively that definite facts about Nature always have their value, but he does not always find it easy to convince the man in the street of this. If there was any branch of science where it appeared difficult, it was perhaps in entomology. The insect pests are our enemies in innumerable ways. We have only just begun serious warfare against them, and the successes which have been won in the last few decades are but a fraction 
of those that may fairly be expected in the decades to come; moreover, our victories over them have a permanence and finality that cannot be hoped for in victories over human enemies. The great strength of our insect enemies has been that for long we did not understand that they were our enemies at all. That lesson once learnt is not likely ever to be forgotten while our civilization endures. But it was not learnt easily. The critics who make merry at the expense of scientific pursuits have seldom been more confident or more utterly wrong than in this instance. For example, Thomas Shadwell, a well-known playwright, published in 1676 a play called "The Virtuoso", in which he satirized the naturalist of the day as Sir Nicholas Gimerack, whom he described as follows : "A coxcomb, he has studied these twenty years about the nature of lice, spiders, and insects . .. no man upon the face of the earth is so well seen in the nature of ants, flies, humble bees, earwigs, hoglice, maggots, mites in cheose, tadpoles, newts, spiders, and all the products of the sun by equivocal genera. tion. This foolish virtuoso does not consider that one bricklayer is worth forty philosophers".

We know now that malaria is transmitted by anopheline mosquitoes, dysentery by the common house-fly, typhus by the louse and plague by fleas. The case of mosquitoes and malaria is of special interest, because it is not just any mosquito but the particular species of anopheles which is recognizable by 'walking on its head'. The recognition of facts like these is in the process of conquering the tropics for civilization, and I think we may fairly claim that it has been proved that if anyone is a 'coxcomb' it is not the naturalists who concern themselves with these insects, but the critics who affect to despise them for doing so. I do not say this in any spirit of selfcomplacency, having myself, many years ago, been unsympathetic to a friend who concerned himself with the close study of fleas infecting various animal species.

In view of facts like those I have mentioned, the Zoology Department of the College under Prof. J. W. Munro has, of recent years, paid special attention to the subject of economic entomology, and has built up a large body of knowledge about insect pests and how to combat them; and when the War came its staff and resources have been used to the full in protecting stocks of grain from insects and rats, and in combating the mosquitoes, flies, and other even less pleasant insects which infect our troops with malaria, yellow fever, sleeping sickness, typhus and plague.

Typhus, there is good reason to believe, killed more people than all the weapons of war during 1914-18. We can scarcely say as yet whether a similar statement would hold for the present War; but most people find it difficult to realize the true bearing of facts of this kind. Many, it may be suspected, picture the horrors of war mainly in terms of bayonet charges and the like, as in the pictures of Napoleon's campaigns ; and, indeed, these are arresting enough : but they only show a minor aspect of the terrible reality. The louse, we now know, is far more deadly than the bayonet.

The successful attack on insect pests has, however, depended to a great extent on the possession of a suitable insecticide to use against them. Supplies of pyrethrum were largely cut off by the entry of Japan into the War, and attention was turned to a new insecticide, D.D.T. Neither this substance itself nor the application as an insecticide is entirely new, but its value has been explored much more fully than before, and it has been used on an unprecedented scale. It is practically without smell, and is very persistent. Thus, when sprayed on walls at a suitable concentration it kills any fly alighting on them up to a period of three weeks. A bed sprayed with it is fatal to bed bugs for three hundred days, and clothing dusted with it is safe from lice for a month, even after several launderings. Impressive though these results are, it is not claimed that D.D.T. is a final solution of all insecticide problems or that it puts all other insecticides out of court.

As we have seen, the insect pests in many cases convey dangerous or deadly infection by their bite, and as we have seen, much is being done to cut off the sources of infection as well as to destroy its insect conveyors. It cannot, however, be claimed that full success has yet been attained in either direction, supposing that the invader has got past our defences, and has effected a lodgment in the human body. Can we still hope to attack him ? Obviously this is a much more difficult matter, and for long it appeared almost hopeless. We can attack micro-organisms or insect enemies with all sorts of more or less poisonous disinfectants such as carbolic acid or D.D.T. when they are outside the human body, but when they have effected a lodgment inside it their position becomes far stronger; for we cannot in general attack the enemy without endangering the friend in whose body he has ensconced himself. You see, then, how difficult the problem is. Light has come from the recent development of penicillin, which while harmless to the patient is poisonous to the invading micro-organisms. Penicillin is the product of a plant mould, and the romantic circumstance is that nearly all the penicillin in use, which is saving lives and relieving anxious hearts all over the world, is the progeny of the single small spot of penicillin mould originally observed by Sir Alexander Fleming. The preparation of concentrated penicillin from it is a matter of no small technical difficulty, and with this and the question of its chemical nature our Organic Chemistry Department under Prof. I. M. Heilbron is vigorously occupied. But our hopes go much further than this. Penicillin is obtained at present from the natural plant source, just as, for example, indigo and a host of other economic products were obtained from plant sources. There is, of course, the difference that indigo is grown in the fields, while penicillin is grown in bottles. But indigo is now made in the chemical factory instead of being obtained from the plant, and the hope is that penicillin may also be produced synthetically, and much more easily and cheaply than now.

Before we try to build up the structure of the penicillin molecule we must, in the first place, have an accurate knowledge of its ultimate composition. That is to say, we must know what kind of atoms, and how many of each, go to build up the structure. That step has now been achieved, but it is by no means enough in itself. To picture what a house is like it is not enough to know what quantities of bricks, slates, timber and so on have been used in building it. You must know how they are arranged. You want an architect's plan. That is what we are trying to make for the penicillin molecule. When the elucidation of the plan of the penicillin molecule made by Nature in the plant has been completed, it will in all probability be possible to build up the same structure in the laboratory by the methods of syn. thetic chemistry, and even to go further by modifying the structure so as to extend its applicability. 